\title{
A massive invasion of fish species after eliminating a natural barrier in the upper rio Paraná basin
}

\author{
Horácio Ferreira Júlio Júnior, Claudenice Dei Tós, Ângelo Antonio Agostinho \\ and Carla Simone Pavanelli
}

Based on long-term studies in the upper rio Paraná basin, in addition to a broad review of literature and other information, we were able to identify 33 species of native fishes in the lower rio Paraná basin that successfully colonized the upper rio Paraná after Itaipu impoundment, that flooded the natural geographic barrier constituted by the Sete Quedas Falls. These species belong to six Orders, encompassing two of Myliobatiformes, six of Characiformes, 17 of Siluriformes, six of Gymnotiformes, one of Perciformes, and one of Pleuronectiformes. Extensive remarks regarding each species, including their influence upon the native assemblage, in addition to comments on other non-indigenous species, are also provided. We conclude that, in spite of its widespread neglected by environmental impact studies, massive invasion of species is a real possibility when natural barriers are suppressed by reservoirs.

Baseando-se em pesquisas de longa duração na bacia do alto rio Paraná, em adição à ampla revisão bibliográfica e outras informações, pudemos reconhecer 33 espécies nativas da bacia do baixo rio Paraná que colonizaram o alto Paraná com sucesso, após a construção de Itaipu, que inundou a barreira geográfica natural constituída pelos Saltos de Sete Quedas. Estas espécies pertencem a seis ordens, incluindo duas de Myliobatiformes, seis de Characiformes, 17 de Siluriformes, seis de Gymnotiformes, uma de Perciformes, e uma de Pleuronectiformes. Extensas observações sobre cada espécie, incluindo a influência delas sobre a assembleia nativa, além de comentários sobre outras espécies não-indígenas são igualmente fornecidos. Nós concluímos que, embora geralmente negligenciadas pelas análises de impactos ambientais, invasões massivas são possibilidades reais quando barreiras naturais são suprimidas por reservatórios.

Key words: Invasive species, Biodiversity, Reservoir Impacts, Ecoregion, Sete Quedas Falls.

\section{Introduction}

Habitat loss and degradation, flow modification, invasive alien species, over-exploitation and pollution are considered the most important impact factors acting on species extinction and threats to biodiversity (Allan \& Flecker, 1993; Naiman \& Turner, 2000; Revenga et al., 2005; Dudgeon et al., 2006; Agostinho et al., 2007a). Concerning freshwater ecosystems, the forefront of the biodiversity crisis, hydrologic alterations and biological invasions represent two of the greatest threats to freshwater biota (Johnson et al., 2008). Although the relationship between these impact sources is not well understood, hydropower impoundments are associated with both of them. Biological invasions are most likely established when native assemblages have been disrupted, and their longterm success (integration) is more probable under the conditions of a permanently altered system (Moyle \& Light, 1996a, 1996b). In Brazil, this situation worsened, because for decades in the last century, alien species stocking was routine in fishery management programs to compensate for the negative impacts of dams on fishing. Today, stocking with non-native species in public waters is forbidden, although some clandestine introductions are still conducted (Zeinad, 2008). However, another problem linked to dam construction that has not received enough attention is the mixing of fish fauna when the impounded area includes natural barriers for dispersion. Because hydropower dams are more efficient in the upper part of the basin, where fish fauna isolation by falls is more likely, elimination of barriers by hundreds of planned hydropower dams needs to be considered during environmental impact studies.

This study analyzes the fish species invasion in the upper

Núcleo de Pesquisas em Limnologia, Ictiologia e Aquicultura (Nupélia), Universidade Estadual de Maringá. Av. Colombo, 5790, 87020-900 Maringá, PR, Brazil. juliojr@nupelia.uem.br 
part of the rio Paraná basin after the Itaipu Reservoir inundated Sete Quedas Falls, a natural and effective barrier that was the limit of two hydrographic ecoregions (sensu Abell et al., 2008). The role of Sete Quedas Falls as a limit of these ichthyofaunistic regions was recognized by Ringuelet (1975) and corroborated by several authors (Bonetto, 1986; Abell et al., 2008) with different names for each ecoregion. The Itaipu Dam, located $150 \mathrm{~km}$ downstream from Sete Quedas, impounded the rio Paraná in 1982 and completely flooded the falls. Therefore, several species endemic to the lower rio Paraná basin successfully colonized and spread over the upper rio Paraná.

Immediately above the Itaipu Reservoir is a large floodplain remnant in the upper rio Paraná basin $(230 \mathrm{~km})$, which is important for conservation because it is one of the last well-preserved areas of the rio Paraná wetlands within Brazil. This floodplain used to extend for more than $400 \mathrm{~km}$ upstream of the Itaipu Reservoir, but half of it was consumed by the Porto Primavera Reservoir in 1998 (Agostinho et al., 2007a).

The main purpose of this paper is to identify the species from the lower part of the rio Paraná basin that dispersed to its upper stretches, giving preliminary information about their success and impacts. A careful report of the entire process of mixing species is essential for understanding the past and current geographic distributions that may subsidize future mitigating actions.

\section{Material and Methods}

Data for this study were gathered prior to the construction of the Itaipu Dam above and below Sete Quedas Falls (CETESB/Itaipu Binacional, 1981) and after its construction in several long-term studies carried out by the "Núcleo de Pesquisas em Limnologia, Ictiologia e Aquicultura” (Nupelia - "Universidade Estadual de Maringá") and supported by Itaipu Binacional and federal research funding agencies ("Conselho Nacional de Desenvolvimento Científico e Tecnológico" - CNPq, "Pesquisas Ecológicas de Longa Duração" - CNPq-PELD, Financiadora de Estudos e Projetos - Finep). Data from the fish fauna surveys carried out during the last decade in stretches of the upper rio Paraná above large dams (e.g., Grande, Paranapanema and Paranaíba rivers) were also used to discriminate non-native species. In addition, numerous taxonomic works, including reports, revisions, surveys and original descriptions, were also considered as well as opinions of expert fishers and other fish professionals. Because of the heterogeneous character of the data, we present only qualitative analysis. Voucher specimens were deposited in the Coleção Ictiológica do Nupélia (NUP), and the catalog numbers are given in Table 1 .

Hydrographic ecoregions follow Abell et al. (2008) for delineation of freshwater regionalization, where ecoregions are defined as large areas "encompassing one or more freshwater systems with a distinct assemblage of natural freshwater communities and species". Species invasions toward the upper rio Paraná ecoregion after removal of the Sete Quedas Falls barrier were considered here as fish introduction.

\section{Results}

Species that successfully colonized the upper rio Paraná basin after the Itaipu dam's closure are listed in Table 1, following the classifications proposed by Nelson (2006) for superior categories and by Reis et al. (2003) for families and subfamilies. The range of distribution of these 33 species upstream from the Itaipu Reservoir is delimited by dams closed before Itaipu Dam, i.e., the Jupiá Dam in the rio Paraná main channel and Capivara Dam in the rio Paranapanema, including all the tributaries of this area (Fig. 1). This figure represents 20.3\% of the total species in this stretch (Graça \& Pavanelli, 2007). The fish fauna are composed mainly of Siluriformes (17 species: 6 Loricariidae, 4 Doradidae, 4 Auchenipteridae and 3 Pimelodidae), Characiformes (6 species: 3 Erythrinidae, 2 Characidae and 1 Curimatidae) and Gymnotiformes (6 species: 2 Gymnotidae, 2 Rhamphichthyidae, 1 Apteronotidae and 1 Hypopomidae), followed by Myliobatiformes (2 Potamotrygonidae), Perciformes (1 Cichlidae) and Pleuronectiformes (1 Achiridae). However, some of them, e.g. Potamotrygon spp., Garrone-Neto et al. (2007), dispersed throughout the Paraná and Tietê rivers, passing through dams using navigation locks. At present, at least 10 of these species reach stretches upstream from the Jupiá Reservoir (i.e., Ageneiosus inermis, Auchenipterus osteomystax, Hypophthalmus edentatus, Loricariichthys platymetopon, Trachelyopterus galeatus, Pimelodus ornatus, Pterodoras granulosus, Serrasalmus marginatus, Rhamphichthys hahni, Sorubim lima), which was closed in 1974, before the Itaipu Dam (CESP, 2005) (Fig. 1).

\section{Discussion}

Several species had uncertain origins for different reasons, and they were not considered here. The two most recent reviews of the fish fauna of the upper rio Paraná basin that considered the Itaipu impoundment are Graça \& Pavanelli (2007) and Langeani et al. (2007). Both works were considered; however, some species (Cynopotamus kincaidi, Metynnis mola, Characidium laterale, Cyphocharax gillii, and Loricaria simillima) listed by Langeani et al. (2007) were not considered here, because they were never collected in the 300-km stretch of river upstream from the Itaipu Reservoir. Currently, some ichthyologists still do not state precisely from which ecoregions of the rio Paraná drainage system their material comes, and sometimes they provide geographical distributions of species without considering the presence of any geographical barriers. This procedure raises several doubts in recognizing if such species are widespread in the rio Paraná drainage system and caused some difficulties in detecting invasive species in the present work.

Ahead, we discuss by family the species introduced in the upper rio Paraná ecoregion due to the loss of the Sete Quedas Falls. 


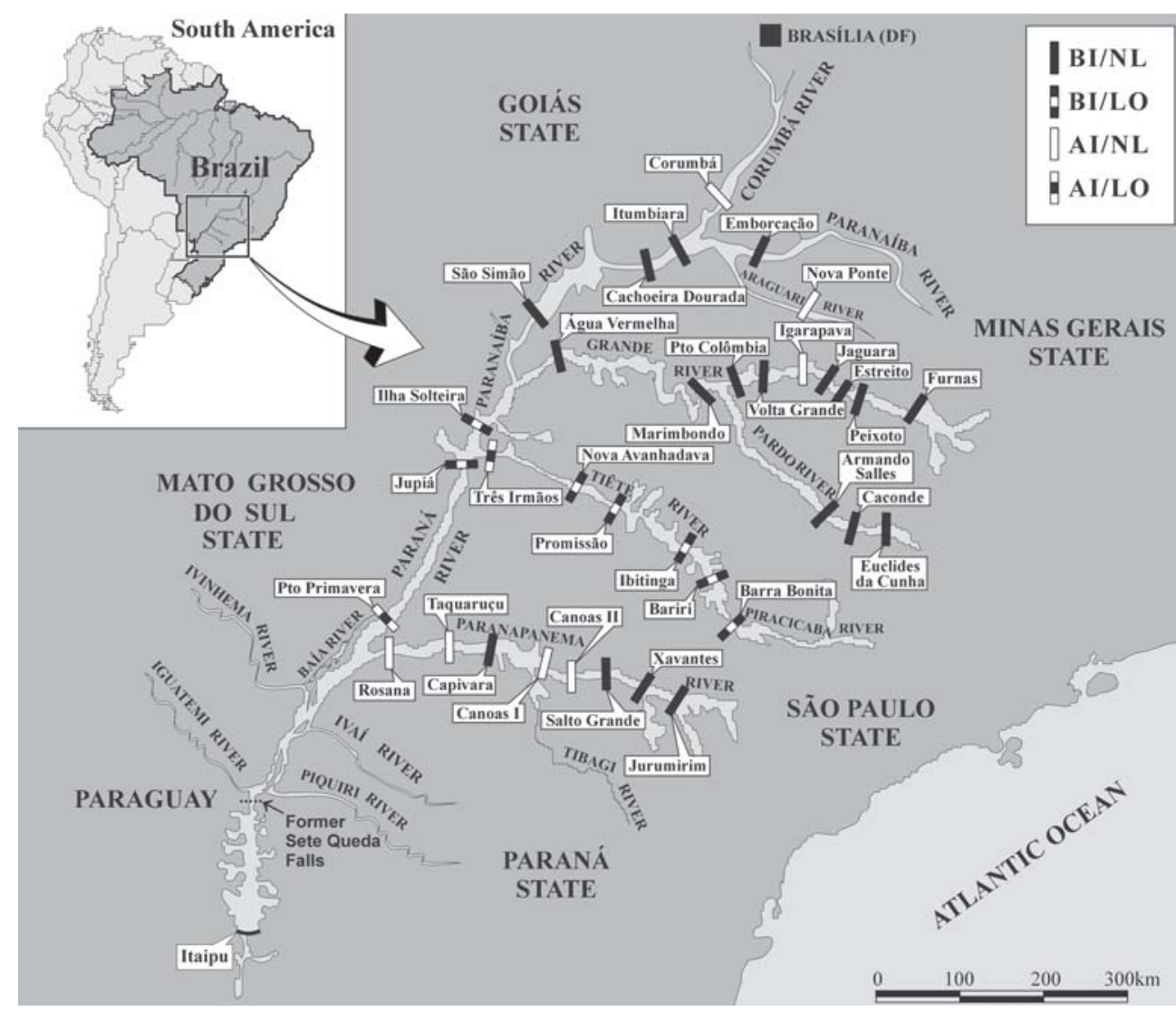

Fig. 1. Location of the former Sete Quedas falls barrier (which used to separate two ichthyofaunistic provinces) and main dams of the upper Paraná River basin (BI/ = closed before Itaipu dam closure; AI/ = closed after Itaipu dam closure; $/ \mathrm{NL}=$ no lock; /LO = lock).

\section{Potamotrygonidae}

The natural distribution of Potamotrygonidae in South America excluded the rio São Francisco basin, rivers that drain into the Atlantic Ocean from the Atlantic rainforest of northeastern and southeastern Brazil, the upper rio Paraná basin and rivers south of the La Plata River in Argentina (Carvalho et al., 2003). In the rio Paraná basin, there are at least six rio Paraná potamotrygonids (P. brachyura, P. castexi, P. falkneri, P. hystrix, P. motoro, and P. schuhmacheri), all of them found just downstream from Sete Quedas Falls. After the impoundment, stingrays appeared in several kinds of environments in the upper rio Paraná basin (Agostinho et al., 2004; Garrone-Neto et al., 2007; Garrone \& Sazima, 2009). Fishers of the floodplain above the Itaipu Reservoir had never seen those fish before; thus, several accidents occurred during fishing, mostly when seining on sand beaches at night. Potamotrygon motoro and P. falkneri are currently very abundant in the upper Paraná.

\section{Curimatidae}

Curimatids are widespread in the Neotropical region (Vari, 2003). However, only one Steindachnerina species was known to be present in the upper rio Paraná: $S$. insculpta, which is abundant in the entire basin. Late last century, another congener was described from the rio Corumbá (an affluent of the rio Paranaíba): S. corumbae, which is endemic to the rio Paraná headwaters (Pavanelli \& Britski, 1999). Steindachnerina brevipinna, which was restricted to the Paraná-Paraguay system below Sete Quedas (Vari, 2003), successfully colonized the upper rio Paraná basin after the construction of the Itaipu Dam, and it is now found syntopically with $S$. insculpta. One of the main differences between the two congeners is a round black blotch on the dorsal fin rays of S. brevipinna that is lacking in S. insculpta. Captures of several individuals with faded blotches caused uncertainties about the existence of hybrids between these species. To elucidate this issue, samples of individuals displaying a very dark, faded or completely absent blotches were compared by the random amplified polymorphic DNA (RAPD) technique in addition to being morphologically analyzed. Occurrences of both species were confirmed, and individuals with a faded blotch were attributed to $S$. brevipinna rather than hybrids (Oliveira et al., 2002).

\section{Characidae}

The largest characiform family, characids are abundant in several environments throughout the Neotropical region. Because of their heterogeneous nature, the species are 
Table 1. Fish species from the lower Paraná River that successfully colonized the upper Paraná River ecoregion after the flooding of the geographical barrier of the Sete Quedas Falls.

\begin{tabular}{|c|c|c|}
\hline \multicolumn{3}{|l|}{ Chondrichthyes } \\
\hline Potamotrygonidae (River stingrays) & $\begin{array}{l}\text { Potamotrygon falkneri Castex \& Maciel, } 1963 \\
\text { Potamotrygon motoro (Müller \& Henle, 1841) }\end{array}$ & $\begin{array}{l}\text { NUP } 2847 \\
\text { NUP } 4419\end{array}$ \\
\hline \multicolumn{3}{|l|}{ Actinopterygii } \\
\hline Curimatidae (Toothless characiforms) & Steindachnerina brevipinna (Eigenmann \& Eigenmann, 1889) & NUP 2895 \\
\hline Characidae (Characins) & $\begin{array}{l}\text { Roeboides descalvadensis Fowler, } 1932 \\
\text { Serrasalmus marginatus Valenciennes, } 1837\end{array}$ & $\begin{array}{l}\text { NUP } 5531 \\
\text { NUP } 404\end{array}$ \\
\hline Erythrinidae (Trahiras) & $\begin{array}{l}\text { Erythrinus erythrinus (Bloch, 1801) } \\
\text { Hoplerythrinus unitaeniatus (Agassiz, 1829) } \\
\text { Hoplias aff. malabaricus (Bloch, 1794) “cytotype c” }\end{array}$ & $\begin{array}{l}\text { NUP } 4158 \\
\text { NUP } 1777 \\
\text { NUP } 3456\end{array}$ \\
\hline \multicolumn{3}{|l|}{ Siluriformes } \\
\hline Loricariidae (Armored catfishes) & $\begin{array}{l}\text { Hypostomus cochliodon Kner, } 1854 \\
\text { Hypostomus commersoni Valenciennes, } 1836 \\
\text { Hypostomus microstomus Weber, } 1987 \\
\text { Hypostomus ternetzi (Boulenger, 1895) } \\
\text { Loricariichthys platymetopon Isbrücker \& Nijssen, } 1979 \\
\text { Loricariichthys rostratus Reis \& Pereira, } 2000\end{array}$ & $\begin{array}{l}\text { NUP } 4074 \\
\text { NUP } 856 \\
\text { NUP } 1725 \\
\text { NUP } 5323 \\
\text { NUP } 2378 \\
\text { NUP } 2550\end{array}$ \\
\hline Pimelodidae (Long-whiskered catfishes) & $\begin{array}{l}\text { Hypophthalmus edentatus Spix \& Agassiz, } 1829 \\
\text { Pimelodus ornatus Kner, } 1858 \\
\text { Sorubim lima (Bloch \& Schneider, 1801) }\end{array}$ & $\begin{array}{l}\text { NUP } 517 \\
\text { NUP } 1870 \\
\text { NUP } 2494\end{array}$ \\
\hline Doradidae (Thorny catfishes) & $\begin{array}{l}\text { Oxydoras eigenmanni Boulenger, } 1895 \\
\text { Platydoras armatulus (Valenciennes,1840) } \\
\text { Pterodoras granulosus (Valenciennes, 1821) } \\
\text { Trachydoras paraguayensis (Eigenmann \& Ward, 1907) }\end{array}$ & $\begin{array}{l}\text { NUP } 5898 \\
\text { NUP } 1840 \\
\text { NUP } 1855 \\
\text { NUP } 1890\end{array}$ \\
\hline Auchenipteridae (Driftwood catfishes) & $\begin{array}{l}\text { Ageneiosus inermis (Linnaeus, 1766) } \\
\text { Ageneiosus ucayalensis Castelnau, 1855 } \\
\text { Auchenipterus osteomystax (Miranda-Ribeiro, 1918) } \\
\text { Trachelyopterus galeatus (Linnaeus, 1766) }\end{array}$ & $\begin{array}{l}\text { NUP } 2007 \\
\text { NUP } 531 \\
\text { NUP } 1468 \\
\text { NUP } 1843\end{array}$ \\
\hline \multicolumn{3}{|l|}{ Gymnotiformes } \\
\hline Gymnotidae (Naked-back knifefishes) & $\begin{array}{l}\text { Gymnotus pantanal Fernandes, Albert, Daniel-Silva, } \\
\text { Lopes, Crampton \& Almeida-Toledo, } 2005 \\
\text { Gymnotus paraguensis Albert \& Crampton, } 2003\end{array}$ & $\begin{array}{l}\text { NUP } 4184 \\
\text { NUP } 4498\end{array}$ \\
\hline Rhamphicthyidae (Sand knifefishes) & $\begin{array}{l}\text { Gymnorhampichthys cf. hypostomus Ellis, } 1912 \\
\text { Rhamphichthys hahni (Meinken, 1937) }\end{array}$ & $\begin{array}{l}\text { NUP } 4170 \\
\text { NUP } 1871\end{array}$ \\
\hline Hypopomidae (Bluntnose knifefishes) & Brachyhypopomus cf. gauderio Giora \& Malabarba, 2009 & NUP 3164 \\
\hline Apteronotidae (Ghost knifefishes) & Apteronotus caudimaculosus Santana, 2003 & NUP 4674 \\
\hline $\begin{array}{l}\text { Perciformes } \\
\quad \text { Cichlidae (Cichlids) }\end{array}$ & Astronotus crassipinis (Heckel, 1840) & NUP 167 \\
\hline $\begin{array}{l}\text { Pleuronectiformes } \\
\text { Achiridae (American soles) }\end{array}$ & Catathyridium jenynsii (Günther, 1862) & NUP 2809 \\
\hline
\end{tabular}

arranged in several subfamilies in addition to many genera incertae sedis, following Lima et al. (2003). In the present study, the characids are presented jointly.

Roeboides descalvadensis, currently considered a seniorsynonym of $R$. paranensis, is widespread in the Amazônia and Paraná-Paraguay basins (Lucena, 2007). Its recent occurrence in the upper rio Paraná basin is due to the flooding of Sete Quedas Falls by Itaipu Reservoir, as can be evidenced by examination of the very extensive analysis material provided by Lucena (2007) when studying that species. The single lot from the upper rio Paraná basin in that list was caught in 2000, almost two decades after Itaipu Dam's closure. Today, $R$. descalvadensis is easily found in the upper rio Paraná. The Coleção Ictiológica do Nupélia (NUP) has 15 lots of the species sampled in the upper rio Paraná, and all of them come from different periods after Itaipu.
The only native piranha to the upper rio Paraná is Serrasalmus maculatus, until recently named S. spilopleura, according to Jégu \& Santos (2001). After the impoundment, the congener $S$. marginatus successfully colonized the upper rio Paraná basin and drastically affected the native species population in that region. Agostinho \& Júlio Jr. (2002), analyzing data from 21 sampling sites in the region of influence of Itaipu Reservoir and in the upper rio Paraná floodplain, detected an increase in the population of $S$. marginatus to the detriment of populations of the native species (S. maculatus). Notwithstanding its small size, $S$. marginatus is gregarious and more aggressive, attacking animals and even humans when taking care of nests or offspring, which explains its colonization success. The current prevalence of $S$. marginatus has caused a misunderstanding about its origin, considering that it was stated as native by Langeani et al. (2007). 


\section{Erythrinidae}

Three erythrinid genera currently occur in the rio Paraná basin, but the greatest number of species in this family is found in the Amazon basin, following Oyakawa (2003). Erythinus erythrinus and Hoplerythrinus unitaeniatus, native in the lower rio Paraná basin, may have dispersed to the upper part after the barrier elimination, but they may have also been introduced by anglers as live bait (Langeani et al., 2007), or both. Another erythrinid widespread in the entire Neotropical region, traditionally identified as Hoplias malabaricus, also occurs in both the upper and lower Paraná. However, Bertollo et al. (2000), studying samples previously identified as $H$. malabaricus, found seven different cytotypes scattered in several Neotropical basins, which they labeled by alphabetic letters. These cytotypes remain taxonomically unstudied and, therefore, are still not formally described. Sympatric cytotypes A and D naturally occur in the upper rio Paraná basin. Cytotype C, which formerly only occurred in the lower Paraná basin, has been caught in the upper Paraná since the barrier removal. In the upper rio Paraná floodplain, the introduced cytotype $\mathrm{C}$ is presently more abundant than cytotypes A and D (Pazza \& Júlio Jr., 2003). Graça \& Pavanelli (2007) preliminarily provided a brief description of the three cytotypes, discriminating them in a key for identification and calling cytotypes C, D and A Hoplias sp. 1, Hoplias sp. 2 and Hoplias sp. 3, respectively.

\section{Loricariidae}

The family Loricariidae (armored catfish) is the largest family of catfishes in the world. Its numerous species are scattered in seven currently recognized subfamilies; however, in the present work, representative species of two subfamilies are presented.

Hypostomus cochliodon, $H$. commersoni and $H$. ternetzi were widespread in the Paraguay and Uruguay rivers and in the rio Paraná downstream from Sete Quedas, according to Carvalho \& Bockmann (2007). These species have been found in the upper Paraná since Itaipu's closure and the barrier disappearance (Graça \& Pavanelli, 2007). Langeani et al. (2007) listed these species as being of unknown origin in the upper rio Paraná basin. Hypostomus microstomus is another loricarid that was previously restricted to waters below Sete Quedas (Weber, 2003) but is now caught in the upper rio Paraná. This finding has been corroborated by Graça \& Pavanelli (2007), but not by Langeani et al. (2007), who listed the species as native to the upper Paraná. Most are commercially important (Delariva \& Agostinho, 2001).

Loricariichthys species are also widespread in South America, but they have never been recorded in the upper rio Paraná, nor in the rio São Francisco basin (Reis \& Pereira, 2000). These authors described Loricariichthys rostratus from the Itaipu Reservoir region and stated that this species was absent in the upper rio Paraná before Itaipu impoundment. They also provided similar comments for $L$. platymetopon, earlier described from the Paraguay River. Both species are currently common in the upper rio Paraná, in particular the former, which is abundant in the upper rio Paraná floodplain.

\section{Pimelodidae}

Pimelodid, as currently defined, presents several modifications if compared to the traditionally accepted definition until late in the last century (Lundberg \& Littmann, 2003). In any case, it encompasses species with a broad range of sizes, and several species are especially important as human food resources. Hypophthalmus edentatus, a zooplanktivorous species, was previously distributed only in the lower Paraná and Amazon basins. In the early years after the Itaipu Reservoir was completed, this species was one of the most abundant, benefitting from the upsurge of organic matter and increasing zooplankton and phytoplankton biomass (Ambrósio et al., 2001; Abujanra \& Agostinho, 2002). Lundberg \& Littmann (2003) reported only H. oremaculatus for the rio Paraná basin, but Graça \& Pavanelli (2007), comparing dispersed individuals with the original description of this species, observed that the characteristics did not match. In addition, Britski et al. (2007) referred only to H. edentatus for the Pantanal (Paraguay River basin).

Pimelodus ornatus, a species with a color pattern quite different from other species of the genus, was restricted to the Paraguay and Paraná Rivers downstream from Sete Quedas Falls and has been caught in the upper rio Paraná basin since the Itaipu impoundment (Graça \& Pavanelli, 2007). In the floodplain stretch, it preferentially inhabits rapids.

Sorubim lima is another pimelodid species that apparently colonized the upper rio Paraná basin, where it was absent before Itaipu's closure as suggested by Langeani et al. (2007), who listed it as being of unknown origin in the upper rio Paraná basin. Corroborating this, in the recent revision of the genus Sorubim, Littman (2007) provides a list composed of more than 80 lots of material examined for that species, but none from the upper Paraná.

\section{Doradidae}

Four thorny catfishes successfully invaded the upper rio Paraná after Itaipu: Oxydoras eigenmanni (= Doras eigenmanni in Zawadzki et al., 1996), Platydoras armatulus, Pterodoras granulosus, and Trachydoras paraguayensis, as already stated by Zawadzki et al. (1996). The only native doradid species upstream from the Falls was Rhinodoras dorbignyi, which remains hitherto cohabiting with congeners. Some of the introduced species became common, such as T. paraguayensis, especially in the years just after the impoundment, and $P$. granulosus, currently the second most important species in biomass considering artisanal fisheries in the Itaipu Reservoir (Okada et al., 2005). Oxydoras kneri is the only thorny catfish native to the rio Paraná basin below Sete Quedas Falls that did not colonize the upper rio Paraná after Itaipu.

\section{Auchenipteridae}

There are six auchenipterid species inhabiting the upper rio Paraná, distributed in the genera Ageneiosus, Auchenipterus, and Trachelyopterus. Two Ageneiosus species colonized the upper Paraná after the Itaipu impoundment: A. inermis (formerly called A. brevifilis) and A. 
ucayalensis. The only Ageneiosus species native to the upper rio Paraná is Ageneiosus militaris (formerly called A. valenciennesi), which is widespread in the whole rio Paraná basin. Species of this genus recently had their names changed following Ferraris Jr. (2003). Misunderstandings regarding their native geographical distributions were noted since Ferraris Jr. (2003) and Langeani et al. (2007) stated that A. ucayalensis was in the upper rio Paraná before Itaipu’s closure. Older checklists, such as Britski (1972) and Walsh (1990), recorded only A. militaris in this ecoregion, and Graça \& Pavanelli (2007) agree with the present work in stating that $A$. inermis and A. ucayalensis dispersed only after the Sete Quedas Falls barrier was eliminated. Auchenipterus was also revised by Ferraris \& Vari (1999), who mentioned that the single representative species in the upper Paraná, $A$. osteomystax, apparently colonized that region after the barrier elimination. Trachelyopterus was recently revised by Akama (2004) and later by Ferraris (2007). Two species of this genus currently occur in the upper rio Paraná basin: Trachelyopterus galeatus and Trachelyopterus sp. The latter is consensually native to the upper rio Paraná, in addition to almost all other Neotropical basins. The former, conversely, was not present in the upper Paraná before the impoundment. On the other hand, Langeani et al. (2007) recorded both species as native to the upper rio Paraná basin. All auchenipterid species successfully colonized the Itaipu Reservoir just after the closure of the dam, except Trachelyopterus sp. (Agostinho et al., 1994).

\section{Gymnotidae}

The only gymnotid genus recorded in the upper rio Paraná basin is Gymnotus, monophyletic and the most diverse and widespread of South American electric fishes (Fernandes et al., 2005), with a single species previously found in this basin: G. carapo. Electrobiological, cytogenetic and molecular studies have shown that Gymnotus currently encompasses numerous different species throughout the Neotropical region, some of which are still undescribed (Campos-da-Paz, 2003). Currently, five Gymnotus species are found in the upper rio Paraná: G. inaequilabiatus, $G$. pantanal, G. paraguensis, G. sylvius and G. pantherinus. The first was described from some imprecise sites, although the type locality has been indicated as the La Plata River. Several individuals previously identified as G. carapo in the whole rio Paraná basin, including the upper, are now attributed to G. inaequilabiatus. All Gymnotus species are frequently used as live bait by anglers, which might cause releases between basins by ill-informed fishers. Graça \& Pavanelli (2007) have considered this possibility to justify the presence of G. pantanal and G. paraguensis in the upper Paraná in addition to the Itaipu impoundment. However, Langeani et al. (2007) consider the former as native species in the upper Paraná basin, attributing to the Itaipu impoundment only the presence of G. paraguensis in this ecoregion. Some Gymnotus species are presently abundant in the upper rio Paraná, mostly in lentic environments.
However, due to misidentifications and further introductions, their genuine origin in that region remains uncertain.

\section{Rhamphichthyidae}

Rhamphichthyids are a small family of knifefishes with a few more than a dozen species (Ferraris Jr., 2003). The colonizer Rhamphichthys hahni (formerly misidentified as $R$. rostratus), currently found in the upper rio Paraná, was consensually absent in this basin before the Itaipu's closure, as stated by several authors, such as Graça \& Pavanelli (2007) and Langeani et al. (2007). Gymnorhamphichthys cf. hypostomus clearly appeared in the upper rio Paraná only recently. Its occurrence is rare and its invasion in the upper Paraná ecoregion can be attributed to the elimination of Sete Quedas Falls by the Itaipu Reservoir.

\section{Hypopomidae}

Brachyhypopomus cf. gauderio also appeared in the upper rio Paraná only recently and its presence can be credited to the Itaipu building as in $G$. cf. hypostomus, since hypopomid species are uncommon in the aquarium trade, they are not consumed (Albert \& Crampton, 2003), and they are rarely used as live bait. The real cause for the current geographical distribution of both Gymnorhamphichthys and Brachyhypopomus species necessarily demands further analysis, such as molecular studies comparing populations from native and invaded habitats. For now, their true origin in this region remain uncertain.

\section{Apteronotidae}

Apteronotus ellisi was the only apteronotid in the upper rio Paraná basin before the Itaipu Reservoir (Britski, 1972). It has been misidentified and has received different names, such as A. brasiliensis, Sternarchus brasiliensis and Porotergus ellisi (Albert, 2003). At present, A. caudimaculosus, associated with aquatic macrophytes (mainly Eichornia and Pistia), has also been caught in the upper rio Paraná. It was not described from this ecoregion or recorded there before Itaipu. Currently it is widespread in the upper stretch, suggesting that it might have invaded after the impoundment. Graça \& Pavanelli (2007), based on the widespread occurrence of that species, even suggested that $A$. caudimaculosus was probably native to this ecoregion. Nevertheless, it was not found in the region of the Itaipu Reservoir sampled just before the closure of the dam (CETESB, 1981). This can be attributed to the use of inadequate fishing gear for capturing such species. Further studies must be carried out for conclusive statements.

\section{Cichlidae}

Cichlids are one of the major vertebrate families occurring on almost all continents and include roughly 1900 species (Kullander, 2003). Due to their varied behavior, often attractive colors and moderate size, they are commonly exploited as ornamental fishes. Two invasive cichlids have been found in the upper rio Paraná. Astronotus crassipinnis, previously misidentified as Astronotus ocellatus in the upper rio Paraná basin, is well appreciated in aquariophily in the world and 
might have been released deliberately in natural habitats by aquarists. This is suggested due to its absence in surveys conducted just below the Sete Quedas Falls before the Itaipu Reservoir (CETESB, 1981) in addition to its late appearance after Itaipu, along with the considerations of expert fishers, who agree with this possibility. That species was successful in the upper rio Paraná mainly in ponds and lagoons.

\section{Achiridae}

Achirids are saltwater and freshwater flatfishes (Ramos, 2003) that encompass eight Neotropical genera. Previously included in the genus Achirus, the only species in the upper rio Paraná basin is Catathyridium jenynsii, which clearly colonized the region after the barrier removal, as already stated by Agostinho et al. (1994).

\section{Other allochthonous species}

Several species with natural distributions in the lower rio Paraná and presences in other South American basins were recorded in the upper rio Paraná ecoregion. Although the origin of these species is uncertain, it is probably not related to the removal of the Sete Quedas Falls barrier by the Itaipu Reservoir. This is the case of Bryconamericus exodon, Hemiodus orthonops, Acestrorhynchus pantaneiro, Lepthoplosternum pectorale, Pimelodella taenioptera and Pseudoplatystoma reticulatum, which appeared in the upper Paraná catches just recently. The functioning of a fish pass (Canal de Piracema) connecting the region just downstream from Itaipu Dam to the Itaipu Reservoir and concluded in late 2002 may be responsible for these introductions (Graça \& Pavanelli, 2007). Bryconamericus exodon, for example, was the most abundant species in the Canal de Piracema. At least ten other species from the lower Paraná, but absent upstream, were captured in surveys conducted in the 10 kilometer long channel (Makrakis et al., 2007).

Other species currently found, but which appeared just recently in the upper Paraná, including Psellogrammus kennedyi and Metynnis lippincottianus (previously called M. maculatus) cited by Graça \& Pavanelli (2007), were excluded from our species list due to their uncertain origins. Eigenmannia trilineata (with some interest as an ornamental fish) was not included in the present work because there is suspicion concerning whether it is the same species described for the lower Paraná, according to Campos-da-Paz (2008, pers. commun.). Aphyocharax anisitsi was listed by Langeani et al. (2007) as invasive due to Itaipu. Nevertheless, a single lot mentioned by Souza-Lima (2003), who revised the genus, collected in the upper rio Paraná in 1982, did not allow this conclusion.

Some invasive species due to the closure of Itaipu Dam were also introduced in the upper rio Paraná basin by other means, as mentioned before. Leporinus macrocephalus, an anostomid from the lower Paraná ecoregion, was intensively stocked (Agostinho et al., 2007b), escaped from aquaculture ponds (Orsi \& Agostinho, 1999), ascended the Itaipu fish passage (Makrakis et al., 2007) and is currently abundant in the upper rio Paraná. Although this species could have dispersed due to the elimination of the Sete Quedas barrier, it was not included because this obstacle suppression probably was not the main reason for its introduction.

In the same way, another anostomid Schizodon borellii is currently very abundant in the whole upper rio Paraná basin as well as the characid Triportheus nematurus. However, both were intensively stocked in several reservoirs located in the upper rio Paraná basin (CESP, 1996) and one cannot determine the main reason for their current success in that ecoregion. As $S$. borelli has been easily caught in different environments of the upper rio Paraná basin over the last few decades (Agostinho et al., 2004), it has led some authors to consider it as native (Langeani et al., 2007). Triportheus nematurus is the current valid name for the species lately called $T$. paranensis, as stated by Malabarba (2004), who described the nomenclatural problems surrounding this species. It naturally occurred only in the lower rio Paraná basin, and its current incidence in the upper Paraná has been attributed to the Itaipu building by some authors (Portugal, 1990; Graça \& Pavanelli 2007; Langeani et al., 2007). Additionally, the occurrence of that species in the Corumbá Reservoir mentioned by Pavanelli et al. (2007) contributed for that uncertainty.

Satanoperca pappaterra was mentioned in the inventory conducted by CETESB (1981), but misidentified as Geophagus jurupari, and its current presence in the upper rio Paraná ecoregion has been sometimes attributed to the impoundment. In fact, this species has been successful in the upper rio Paraná, in different environments, after the Itaipu building, but his old occurrence in several reservoirs in the upper rio Paraná, even in some closed before Itaipu, also generated doubts about its main origin. In the same way, Pterygoplichthys ambrosettii, a very important loricarid species in the upper rio Paraná floodplain, mainly considering its biomass, also has uncertain origin in that ecoregion. However, aquariophily can be added as one of the reasons for its current distribution.

\section{Final consideration and implications for biodiversity conservation}

Although the upper rio Paraná is a discrete ichthyological ecoregion, it has several species in common with the lower Paraná (Hubert \& Renno, 2006). Large migratory fishes like Salminus brasiliensis (dourado), Pseudoplatystoma corruscans (pintado), Brycon orbignyanus (piracanjuva), Pinirampus pirinampu (barbado), Hemisorubim platyrhynchos (jurupoca), Prochilodus lineatus (corimba), Piaractus mesopotamicus (pacú) and Zungaro jahu (jaú) are common in both ecoregions. Population genetics studies of some of these species above and below the Itaipu Dam suggest they are not isolated populations (Bignoto et al., 2009). These findings suggest that in years of very high discharge, individuals of large migratory species were able to cross the barrier of the Sete Quedas Falls in both directions. It is noticeable that the great majority of fish species that ascended 
to the upper rio Paraná ecoregion after the Itaipu Dam closure are essentially sedentaries or short-distance migrators. However, there are more endemic species in the lower than in the upper rio Paraná, indicating that the falls are effective as a geographical barrier for fish going upstream, rather than downstream.

This study, despite covering a wide range of temporal and spatial databases along with extensive sampling and bibliographic inventories, cannot be considered conclusive. There are several explanations for this (e.g., misidentifications, sampling failures, inadequate fishing gear for some species, mistakes in collection databases, contradictory information, and clandestine stocking). Rather, it is an initial step for further work on the subject. Continuous monitoring in both ecoregions is essential for the future understanding of fish assemblage organization.

Knowing the original geographic distributions of fish species might contribute to preventing new invasions, since governmental agencies depend on this information in making laws and decisions to prevent species introduction and to control those already established. Furthermore, our results show that massive introduction is a real possibility when natural barriers are suppressed by dam construction. Thus, decisions about new impoundments must be considered in addition to the impacts of habitat loss, change or fragmentation, the huge impacts on the native fish fauna expected from massive species invasions. Our results also recommend attention from those who devise reservoir management strategies to enhance fisheries and conservation of water resources, especially concerning fish passes, stocking and use of live bait for fishing.

\section{Acknowledgements}

The authors are grateful to the Núcleo de Pesquisas em Limnologia, Ictiologia e Aquicultura (Nupélia) at Universidade Estadual de Maringá for logistic support, to CNPq/PELD and Itaipu Binacional for financial support, to Luiz Carlos Gomes and Weferson Júnio da Graça for suggestions on the manuscript and Jaime Luiz Lopes Pereira for drawing the figure.

\section{Literature Cited}

Abell, R., M. L. Thieme, C. Revenga, M. Bryer, M. Kottelat, N. Bogutskaya, B. Coad, N. Mandrak, S. L. Balderas, W. Bussing, M. L. J. Stiassny, P. Skelton, G. R. Allen, P. Unmack, A. Naseka, R. Ng, N. Sindorf, J. Robertson, E. Armijo, J. Y. Higgins, T. J. Heibel, E. Wikramanayake, D. Olson, H. L. López, R. E. Reis, J. G. Lundberg, M. H. S. Pérez \& P. Petry. 2008. Freshwater ecoregions of the world: a new map of biogeographic units for freshwater biodiversity conservation. Bioscience, 58(5): 403-414.

Abujanra, F. \& A. A. Agostinho. 2002. Dieta de Hypophthalmus edentatus (Spix, 1829), (Siluriformes, Hypophthalmidae) e variações de seu estoque no reservatório de Itaipu. Acta Scientiarum, Biological Sciences, 24(2): 401-410.
Agostinho, A. A., F. M. Pelicice, A. C. Petry, L. C. Gomes \& H. F. Júlio Jr. 2007a. Fish diversity in the upper Paraná River basin: habitats, fisheries, management and conservation. Aquatic Ecosystem Health Management, 10(2): 174-186.

Agostinho, A. A., H. F. Júlio Jr. \& M. Petrere Jr. 1994. Itaipu reservoir: impacts of the impoundment on fish fauna and fisheries. Pp.171-184. In: I. G. Cowx (Ed.). Rehabilitation of Freshwaters Fisheries. Oxford, Blackwell Scientific Publications, 486p.

Agostinho, A. A., L. C. Gomes \& F. M. Pelicice. 2007b. Ecologia e Manejo dos Recursos Pesqueiros em Reservatórios do Brasil. Maringá, Eduem, 501p.

Agostinho, A. A., L. Rodrigues, L. C. Gomes, S. M. Thomaz \& L. E. Miranda. 2004. Structure and functioning of the Paraná River and its floodplain-LTER site 6. Maringá, Eduem, 275p.

Agostinho, C. S. \& H. F. Júlio Jr. 2002. Observation of an invasion of the piranha Serrasalmus marginatus Valenciennes, 1847 (Osteichthyes, Serrasalmidae) into the upper Paraná River, Brazil. Acta Scientiarum, Biological Sciences, 24(2): 391-395.

Akama, A. 2004. Revisão sistemática dos gêneros Parauchenipterus Bleker, 1862 e Trachelyopterus Valenciennes, 1840 (Siluriformes, Auchenipteridae). Unpublished Ph.D. Dissertation, Universidade de São Paulo, São Paulo, 300p.

Albert, J. S. 2003. Family Apteronotidae (Ghost knifefishes). Pp. 497-502. In: Reis, R. E., S. O. Kullander \& C. Ferraris Jr. (Eds.). Check List of the Freshwater Fishes of South and Central America. Porto Alegre, Edipucrs, 729p.

Albert, J. S. \& W. G. R. Crampton. 2003. Seven new species of the Neotropical electric fish Gymnotus (Teleostei, Gymnotiformes) with a redescription of G. carapo (Linnaeus). Zootaxa, 287: 154.

Allan, J. D. \& A. S. Flecker. 1993. Biodiversity Conservation in Running Waters. Bioscience, 43(1): 32-43.

Ambrósio, A. M., A. A. Agostinho, L. C. Gomes \& E. K. Okada. 2001. The fishery and fishery yield of Hypophthalmus edentatus (Spix, 1829), (Siluriformes, Hypophthalmidae), in the Itaipu reservoir, Paraná state, Brazil. Acta Limnológica Brasiliensia, 13(1): 93-105.

Bertollo, L. A. C., G. G. Born, J. A. Dergam, A. S. Fenocchio \& O. Moreira Filho. 2000. A biodiversity approach in the Neotropical Erythrinidae fish, Hoplias malabaricus. Karyotypic survey, geographic distribution of cytotypes and cytotaxonomic considerations. Chromosome Research, 8: 603-613.

Bignoto, T. S., A. J. Prioli, S. M. A. P. Prioli, T. C. Maniglia, T. A. Boni, L. C. Lúcio, V. N. Gomes, R. A. Prioli, A. V. Oliveira, H. F. Júlio Jr. \& L. M. Prioli. 2009. Genetic divergence between Pseudoplatystoma corruscans and Pseudoplatystoma reticulatum (Siluriformes, Pimelodidae) in the Paraná River Basin. Brazilian Journal of Biology, 69(2): 631-637.

Bonetto, A. A. 1986. The Paraná river system. Pp. 541-556. In: Davies, B. R. \& K. F. Walker (Eds.). The ecology of river systems. Dordrecht, Dr. Junk, 793p.

Britski, H. A. 1972. Peixes de água doce do Estado de São Paulo. Pp. 79-108. In: Comissão Interestadual da Bacia Paraná-Uruguai. Poluição e Piscicultura. São Paulo, Faculdade de Saúde Pública da USP, Instituto de Pesca, 216p.

Britski, H. A., K. Z. S. Silimon \& B. S. Lopes. 2007. Peixes do Pantanal: manual de identificação. Brasília, Embrapa, 227p.

Campos-da-Paz, R. 2003. Family Gymnotidae (naked-back knifefishes). Pp. 483-486. In: Reis, R. E., S. O. Kullander \& C. Ferraris Jr. (Eds.). Check List of the Freshwater Fishes of South and Central America. Porto Alegre, Edipucrs, 729p. 
Carvalho, M. \& F. A. Bockmann. 2007. Família Loricariidae: Hypostominae. Pp. 91-98. In: Buckup, P. A., N. A. Menezes \& M. S. A. Ghazzi (Eds.). Catálogo de espécies de peixes de água doce do Brasil. Rio de Janeiro, Museu Nacional, 195p.

Carvalho, M. R., N. R. Lovejoy \& R. S. Rosa. 2003. Family Potamotrygonidae. Pp. 22-28. In: Reis, R. E., S. O. Kullander \& C. Ferraris Jr. (Eds.). Check List of the Freshwater Fishes of South and Central America. Porto Alegre, Edipucrs, 729p.

CESP. Companhia Energética de São Paulo. 1996. Aspectos limnológicos, ictiológicos e pesqueiros de reservatórios da CESP no Período de 1986 a 1994. São Paulo, CESP, 81p.

CESP. Companhia Energética de São Paulo. 2005. São Paulo, Programa de Manejo Pesqueiro. São Paulo, CESP, 264p.

CETESB/ITAIPU BINACIONAL. 1981. Ictiofauna: Complementação do inventário ictiofaunístico, vol.3 B, Technical Report. Curitiba, CETESB, 98p.

Delariva, R. L. \& A. A. Agostinho. 2001. Relationship between morphology and diets of six neotropical loricariids. Journal of Fish Biology, 58: 832-847.

Dudgeon, D., A. H. Arthington, M. O. Gessner, Z. I. Kawabata, D. J. Knowler, C. Leveque, R. J. Naiman, A. H. Prieur-Richard, D. Soto, M. L. J. Stiassny \& C. A. Sullivan. 2006. Freshwater biodiversity: importance, threats, status and conservation challenges. Biological Review, 81: 163-182.

Fernandes, F. M. C., J. S. Albert, M. F. Z. Daniel-Silva, C. E. Lopes, W. G. R. Crampton \& L. F. Almeida-Toledo. 2005. A new Gymnotus (Teleostei: Gymnotiformes: Gymnotidae) from the Pantanal Matogrossense of Brazil and adjacent drainages: continued documentation of a cryptic fauna. Zootaxa, 993: 114.

Ferraris Jr., C. J. \& R. P. Vari. 1999. The South American catfish genus Auchenipterus Valenciennes, 1848 (Ostariophysi: Siluriformes: Auchenipteridae): Monophyly and relationships, with a revisionary study. Zoological Journal of the Linnean Society, 126: 387-450.

Ferraris Jr., C. J. 2003. Family Auchenipteridae. Pp. 470-483. In: Reis, R. E., S. O. Kullander \& C. Ferraris Jr. (Eds.). Check List of the Freshwater Fishes of South and Central America. Porto Alegre, Edipucrs, 729p.

Ferraris Jr., C. J. 2007. Checklist of catfishes, recent and fossil (Osteichthyes: Siluriformes), and catalogue of siluriform primary types. Zootaxa, 1418: 1-628.

Garavello, J. C. \& H. A. Britski. 1990. Duas novas espécies do gênero Schizodon Agassiz da bacia do alto Paraná, Brasil, América do Sul (Ostariophysi, Anostomidae). Naturalia, 15: 153-170.

Garrone-Neto, D., V. Haddad Jr., M. J. A.Vilela \& V. S. Uieda. 2007. Registro de ocorrência de duas espécies de potamotrigonídeos na região do alto rio Paraná e algumas considerações sobre sua biologia. Biota Neotropica, 7(1): 205-208.

Garrone-Neto, D. \& I. Sazima. 2009. Stirring, charging and picking: huntings tatics of potamotrygonid rays in the upper Paraná River. Neotropical Icthyology, 7(1): 113-116.

Graça, W. J. \& C. S. Pavanelli. 2007. Peixes da planície de inundação do alto rio Paraná e áreas adjacentes. Maringá, Eduem, 241p.

Hubert, N. \& J. F. Renno. 2006. Historical biogeography of South American freshwater fishes. Journal of Biogeography, 33(8): 1414-1436.

Jegú, M. \& G. M. Santos. 2001. Mise au point a propos de Serrasalmus spilopleura Kner, 1858 et réhabilitation de $S$. maculatus Kner, 1858 (Characidae:Serrasalminae). Cybium, 25(2): 119-143.
Johnson, P. T. J., J. D. Olden \& M. J. V. Zanden. 2008. Dam invaders: impoundments facilitate biological invasions into freshwaters. Frontiers in Ecology and the Environment, 6(7): 357-363.

Kullander, S. O. 2003. Family Cichlidae (Cichlids). Pp. 605-656. In: Reis, R. E., S. O. Kullander \& C. Ferraris Jr. (Eds.). Check List of the Freshwater Fishes of South and Central America. Porto Alegre, Edipucrs, 729p.

Langeani, F., R. M. C. Castro, O. T. Oyakawa, O. A. Shibatta, C. S. Pavanelli \& L. Casatti. 2007. Diversidade da ictiofauna do alto rio Paraná: composição atual e perspectivas futuras. Biota Neotropica, 7(3): 1-17.

Lima, F. C. T., L. R. Malabarba, P. A. Buckup, J. F. Pezzi da Silva, R. P. Vari, A. Harold, R. Benine, O. T. Oyakawa, C. S. Pavanelli, N. A. Menezes, C. A. S. Lucena, M. C. S. L. Malabarba, Z. M. S. Lucena, R. E. Reis, F. Langeani, L. Casatti, V. A. Bertaco, C. Moreira \& P. H. F. Lucinda. 2003. Genera Incertae Sedis in Characidae. Pp. 106-169. In: Reis, R. E., S. O. Kullander \& C. Ferraris Jr. (Eds.). Check List of the Freshwater Fishes of South and Central America. Porto Alegre, Edipucrs, 729p.

Lima, R. S. 2003. Revisão taxonômica do gênero Aphyocharax Günther, 1868 (Aphyocharacinae, Characidae, Ostariophysi). Unpublished Ph.D. Dissertation, Universidade de São Paulo, São Paulo, 305p.

Littmann, M. W. 2007. Systematic review of the Neotropical shovelnose catfish genus Sorubim Cuvier (Siluriformes, Pimelodidae). Zootaxa, 1422: 1-29.

Lucena, C. A. S. 2007. Revisão taxonômica do gênero Roeboides grupo affinis (Ostariophysi, Characiformes, Characidae). Iheringia, Série Zoologia, 97(2): 117-136.

Lucena, C. A. S. \& N. A. Menezes. 2003. Subfamily Characinae. Pp. 200-208. In: Reis, R. E., S. O. Kullander \& C. Ferraris Jr. (Eds.). Check List of the Freshwater Fishes of South and Central America. Porto Alegre, Edipucrs, 729p.

Lundberg, J. G. \& M. W. Littmann. 2003. Family Pimelodidae (Longwiskered catfishes). Pp. 432-446. In: Reis, R. E., S. O. Kullander \& C. Ferraris Jr. (Eds.). Check List of the Freshwater Fishes of South and Central America. Porto Alegre, Edipucrs, 729p.

Makrakis, S., L. C. Gomes, M. C. Makrakis, D. R. Fernandez \& C. S. Pavanelli. 2007. The canal da Piracema at Itaipu dam as fish pass system. Neotropical Ichthyology, 5(2): 185-195.

Malabarba, M. C. S. L. 2004. Revision of the Neotropical genus Triportheus Cope, 1872 (Characiformes, Characidae). Neotropical Ichthyology, 2(4): 167-204.

Moyle, P. B. \& T. Light. 1996a. Biological invasions of freshwater: empirical rules and assembly theory. Biological Conservation, 78: 149-161.

Moyle, P. B. \& T. Light. 1996b. Fish invasions in California: do abiotic factors determine success? Ecology, 7(6): 1666-1670.

Naiman, R. J. \& M. G. Turner. 2000. A future perspective on North America's freshwater ecosystems. Ecological Applications, 10(4): 958-970.

Nelson, J. S., 2006. Fishes of the world. $4^{\text {th }}$ ed. New York, John Wiley and Sons, 601p.

Okada, E. K., A. A. Agostinho \& L. C. Gomes. 2005. Spatial and temporal gradients in artisanal fisheries of a large Neotropical reservoir, the Itaipu Reservoir, Brazil. Canadian Journal of Fisheries and Aquatic Sciences, 62: 714-724.

Oliveira, A. V., A. J. Prioli, S. M. A. P. Prioli, C. S. Pavanelli, H. F. Júlio Jr. \& R. S. Panarari. 2002. Diversity and genetic distance in populations of Steindachnerina in the upper Paraná river floodplain of Brazil. Genetica, 115: 259-267. 
Pavanelli, C. S., W. J. Graça, C. H. Zawadzki, H. A. Britski, A. P. Vidotti, G. S. Avelino \& S. Veríssimo. 2007. Fishes from the Corumbá Reservoir, Paranaíba River drainage, upper Paraná River basin, State of Goiás, Brazil. Check List, 3(1): 58-64.

Orsi, M. L. \& A. A. Agostinho. 1999. Introdução de espécies de peixes por escapes acidentais de tanques de cultivo em rios da bacia do Rio Paraná, Brasil. Revista Brasileira de Zoologia, 16(2): 557-560.

Oyakawa, O. T. 2003. Family Erythrinidae (Trahiras). Pp. 238240. In: Reis, R. E., S. O. Kullander \& C. Ferraris Jr. (Eds.). Check List of the Freshwater Fishes of South and Central America. Porto Alegre, Edipucrs, 729p.

Pavanelli, C. S. \& H. A. Britski. 1999. Description of a new species of Steindachnerina (Teleostei: Characiformes: Curimatidae) from the upper Paraná river basin, Brazil. Ichthyological Exploration of Freshwaters, 10: 211-216.

Pazza, R. \& H. F. Júlio Jr. 2003. Occurrence of three sympatric cytotypes of Hoplias malabaricus (Pisces, Erythrinidae) in the upper Paraná river floodplain (Brazil). Cytologia, 68: 159163.

Portugal, L. P. S. 1990. Revisão sistemática do gênero Triportheus Cope (Teleostei, Characiformes, Characidae). Unpublished MSc. Dissertation, Universidade de São Paulo, São Paulo, 192p.

Ramos, R. T. C. 2003. Family Achiridae (American soles). Pp. 666669. In: Reis, R. E., S. O. Kullander \& C. Ferraris Jr. (Eds.). Check List of the Freshwater Fishes of South and Central America. Porto Alegre, Edipucrs, 729p.

Reis, R. E., S. O. Kullander \& C. J. Ferraris Jr. 2003. Check list of the Freshwater Fishes of South and Central America. Porto Alegre, Edipucrs, 729p.

Reis, R. E. \& E. H. L. Pereira. 2000. Three new species of the loricariid catfish genus Loricariichthys (Teleostei: Siluriformes) from Southern South America. Copeia, 2000(4): 1029-1047.

Revenga, C., I. Campbell, R. Abell, P. de Villiers \& M. Bryer. 2005. Prospects for monitoring freshwater ecosystems towards the 2010 targets. Philosophical Transactions of the Royal Society Bulletin, 360: 397-413.

Ringuelet, R. A. 1975. Zoogeografia y ecologia de los peces de aguas continentales de la Argentina y consideraciones sobre las areas ictiologicas de America del Sud. Ecosur, 2(3): 1-122.

Vari, R. P. 2003. Family Curimatidae. Pp. 51-64. In: Reis, R. E., S. O. Kullander \& C. Ferraris Jr. (Eds.). Check List of the Freshwater Fishes of South and Central America. Porto Alegre, Edipucrs, 729p.

Walsh, J. 1990. A systematic revision of the Neotropical catfish family Ageneiosidae (Teleostei: Ostariophysi, Siluriformes). Unpublished Ph.D. Dissertation, University of Florida, Gainesville, 362p.

Weber, C. 2003. Subfamily Hypostominae. Pp. 351-372. In: Reis, R. E., S. O. Kullander \& C. Ferraris Jr. (Eds.). Check List of the Freshwater Fishes of South and Central America. Porto Alegre, Edipucrs, 729p.

Zawadzki, C. H., C. S. Pavanelli \& H. F. Júlio Jr. 1996. Caracterização morfológica e distribuição das espécies da família Doradidae (Pisces, Siluriformes) no alto e médio rio Paraná: registros e comentários. Arquivos de Biologia e Tecnologia, 39(2): 409417.

Zeinad, A. K. 2008. Translocações tresloucadas. Pesca Esportiva, 135: 32-35. 